University of Louisville

ThinkIR: The University of Louisville's Institutional Repository

Electronic Theses and Dissertations

$12-2013$

\title{
Privatization and ethical implications for public managers.
}

Eric Dennison 1979-

University of Louisville

Follow this and additional works at: https://ir.library.louisville.edu/etd

\section{Recommended Citation}

Dennison, Eric 1979-, "Privatization and ethical implications for public managers." (2013). Electronic Theses and Dissertations. Paper 335.

https://doi.org/10.18297/etd/335

This Master's Thesis is brought to you for free and open access by ThinkIR: The University of Louisville's Institutional Repository. It has been accepted for inclusion in Electronic Theses and Dissertations by an authorized administrator of ThinkIR: The University of Louisville's Institutional Repository. This title appears here courtesy of the author, who has retained all other copyrights. For more information, please contact thinkir@louisville.edu. 
PRIVATIZATION AND ETHICAL IMPLICATIONS FOR PUBLIC MANAGERS

\author{
By \\ Eric Dennison \\ B.A. University of Louisville, 2007 \\ A Thesis \\ Submitted to the Faculty of the \\ College of Arts and Sciences of the University of Louisville \\ in Partial Fulfillment of the Requirements \\ for the Degree of
}

Master of Public Administration

Department of Urban Studies

University of Louisville

Louisville, Kentucky

December 2013 
Copyright 2013 by Eric Dennison

All rights reserved 

PRIVATIZATION AND ETHICAL IMPLICATIONS FOR PUBLIC MANAGERS

\author{
By \\ Eric Dennison \\ B.A. University of Louisville 2007 \\ A Thesis Approved on
}

December 6, 2013

by the following Thesis Committee:

Dr Steven Koven

Dr. Janet Kelly

Dr. Robert Pennington 


\section{ABSTRACT \\ PRIVATIZATION AND ETHICAL IMPLICATIONS FOR PUBLIC MANAGERS}

Eric Dennison

December 6, 2013

This Thesis is an examination of privatization and the ethical implications for public managers. It begins with a historical overview of public administration, followed by discussion of the ethical concerns. Case studies show private companies have gained an upper hand in contract negotiations, and public managers have failed to keep the public trust by offering long term contracts that result in monopolies from closed or no bid contract systems. The thesis addresses ways to improve ethical decision making through better regulations and teaching. As privatization becomes a more viable way to pay for government services, the public administrator must maintain a higher level of ethical competency in dealing with this issue. 


\section{TABLE OF CONTENTS}

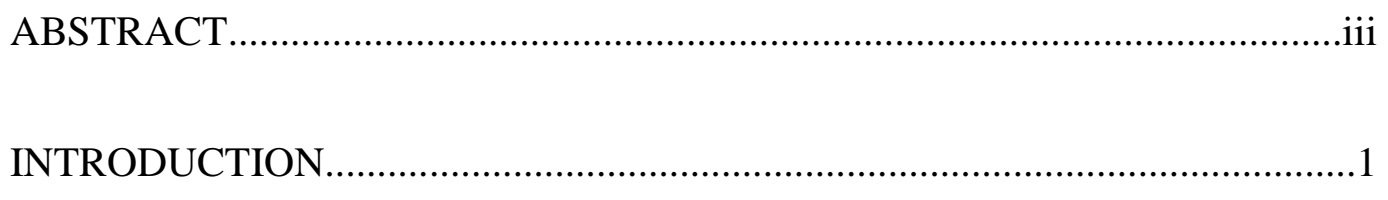

PRIOR PRIVATIZATION STUDIES ................................................... 10

ASSESSING PROCEDURES AND IMPACTS IN PRIVATIZATION..............31

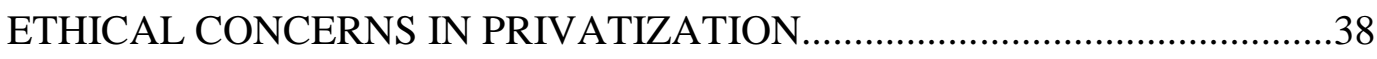

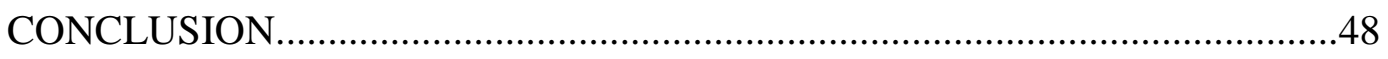

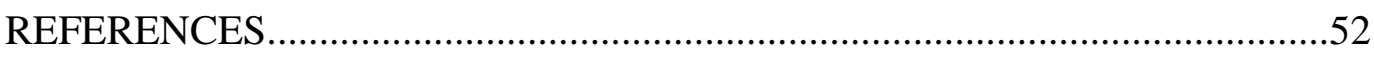

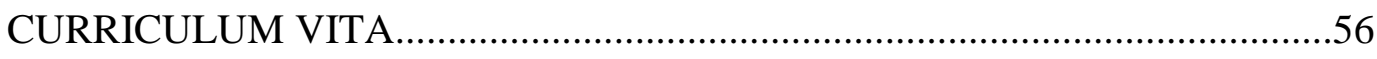




\section{INTRODUCTION}

Many issues exist in the public administration field in trying to administer government and public affairs through an efficient and scientific means outside of politics. Dwight Waldo $(1955,1)$ states, "public administration is the organization and management of men and materials to achieve the purposes of government. Public administration is the art and science of management as applied to affairs of the state."

Public administration is defined as the process of running government and its many functions. This can also include any area within the public sector from non-profit to federal, state and local governments.

The field of public administration transformed into a science around the

beginning of the $20^{\text {th }}$ century, during the progressive era. In 1887, Woodrow Wilson $(1887,482)$ wrote, "administration lies outside the proper sphere of politics.

Administrative questions are not political questions. Although politics sets the tasks for administration, it should not be suffered to manipulate its offices."

Public administration focuses on the bureaucracy and the mechanics of running government. Budgeting, statistics, ethical evaluation, planning program evaluation and various other techniques all reside inside public administration and attempt to run the matrix of government and non-profit institutions. The techniques are used in an effort 
towards making the processes more effective. By using budgeting, statistics, ethical evaluation, planning, program evaluation and various other inputs, these fields all reside inside of public administration and attempt to run the matrix of what is government and public institutions including non-profit. The information collected is used towards making those process more effective.

Public administration can include anyone or any type of bureaucracy from state and local government to the national level to nonprofit work. The field incorporates public policy and implementation. While some would argue that since public administration deals with politics, the science cannot really be objective, however the focus remains highly on administrative duties and how those processes work.

Many issues remain prevalent in the field of public administration, from dealing with efficiency to ethics, to making it a more exact science. Within each of these areas, public administrators try to expand the discipline. The idea of privatization still turns many people's heads and can often times start frank discussions about political stereotypes. Ethics helps to make good decisions as a public administrator. Administrators play many and make difficult decisions. What helps with their decision process is ethics.

Privatization is defined as the transfer of services or ownership of public property or public services to private business. "In the broadest definition, one which emphasizes a philosophical basis, privatization means relying more on the private institutions of society and less on government (the state) to satisfy people's needs. These private institutions include: the market-place and businesses operating therein; voluntary organizations 
(religious, neighborhood, civic, cooperative and charitable, for example); and the individual, family, clan or tribe. According to a second and more operational definition, privatization is the act of reducing the role of government, or increasing the role of the private sector, in an activity or in the ownership of assets." (Savas 2000,10)

The reason for making this transfer of privatization is for reasons of efficiency dealing with cost, labor, and time. This transfer of public good to private enterprise has affected many areas of government from toll roads, to health services, to utilities.

Privatization deals with many different aspects of public administration such as contracting. One large issue becomes the ethical consideration of making such deals that contract the government with private business. The public administrator must always have the public's interest in mind and is at the forefront of all decision making. From the political, to cost and efficiency, the perspectives must be thoroughly thought through in order to pursue a deal.

With some of the examples listed, one idea that needs to be expanded upon is that of equity and public interest. What is equity? Equity can be a hard to define in terms of public interest. Montgomery van Wart $(1996,526)$ states, "one defines public interest primarily in terms of social equity. The social-equity definition of public interest seems to further divide into an external focus and an internal focus. The external focus concentrates on those less fortunate, those less powerful, those deserving of compassion, and those in urgent need. Sometimes such an external focus is termed benevolence. The internal focus concentrates on those in the organization or those who conceivably have a right to be in the organization." 
With privatization, equity can also be further defined as both parties, government and private business as obtaining an equal deal, where both parties benefit from contracting. As with the following Halliburton example, Halliburton clearly benefited from no bidding contract and was able to make lucrative profits, where the government did not. In many of the examples given later, equity becomes a huge issue where it is not met in terms of the public interest being ignored.

The political realm must be on the public administrator's mind when dealing with opening bids and contract negotiations with a company. Any company viewed negatively can often cause a backlash. Halliburton in the 1990's was seen as unscrupulous in its dealing with the government in overcharging for army services. (Ferrell 2013)

Ruben Berrios $(2006,125)$ states some facts about the Iraq war and defense contracts that one might have to call into question:

"When the U.S. became involved in Iraq, bidding for contracts was restricted and the selection process accelerated. As contracts to restore infrastructure and provide services were awarded, European companies were kept out of the lucrative deals. In the provision of certain types of reconstruction and services, defense contracts went to large established contractors in the U.S. One of those lucrative awards went to the Bechtel Group for $\$ 680$ million to help rebuild Iraq's infrastructure. Bechtel had posted revenue of $\$ 11.6$ billion in 2002."

He also goes on to state, "The Defense Contract Audit Agency has found \$219 million in questionable costs in this Restore Iraqi Oil (RIO) contract worth approximately 
$\$ 2.5$ billion. A second RIO contract was awarded to Halliburton worth approximately \$1.2 billion." (Berrios 2006, 126)

Through out the above example, contracts were given out with no oversight or accountability. Halliburton was able to ask for its own prices for out of scope activities and seems to be inappropriately awarded based on no competition, but rather from personal contacts within the government. The questionable contract services also extended to misuse of personal services, supply schedules were missed and almost no oversight over the contract to ensure the contract was carried out appropriately. Equity was not met on both ends of the contract.

Privatization can and should be more efficient. The advantage of contracting services deals with cost and efficiency. If a private company can perform the service cheaper than government, it should theoretically cost the tax payer and citizen less in order to receive a service they need. However, as the case studies below show, this is not always the case and privatization can cost the public more than originally anticipated.

Overall, the public administrator must look at the goals set out hoping to be accomplished by the privatization. In the case in Chicago, where meters where privatized out, the citizens of the city ended up paying almost $400 \%$ mark up over original meter cost and according to Chicago's inspector general, the city could have reaped an additional 1 billion if it raised the rates itself and kept the proceeds. (Koven 2010, 148) The goal had been to increase revenue to pay for services the city needed, but by placing the short term need over the long term, the public lost in this deal. 
While many issues arise from dealing with privatization, one major problem facing the intellectual world of public administration and the real world implications of privatization deals with the ethics of how privatization is implemented.

Ethics can be defined in many different ways, from legal, to personal moral ethics, to organizational ethics. This paper seeks to look at the negative aspects of privatization and show how certain behavior can result in outcomes negative to the public interest from lack of training and oversight can lead to negative dealings with private companies. The ethical viewpoint attempts to uncover the larger implications of privatization abuse. Equity is a goal that must be achieved. Equity can be defined by the appropriate equality or fairness of the contract.

As a way to give the impression of smaller government, often the government will contract out services to private companies to reduce the number of government employees and lower cost. The problem arises when public managers contract for services with no formal public bidding system put into place. When these contract situations arise, no formal public bidding system is put into place, companies are given monopolies and this creates inequity for tax payers and institutions. Private companies are generally savvier at business transactions and thus often get better incentives when dealing with government contracts. Companies are given monopolies and this increases cost for taxpayers and public agencies. Private companies may get generous incentives when dealing with the government.

The crux of this problem revolves around the ethical duties of public managers in this situation and the public manager's duty to the citizen's he/she administrates over. 
Also, this ethical perspective will cover the idea of competency, in that better training of public managers should help them keep their constituents in mind when dealing with these transactions. There seems to be a need for public managers to have better training, and thus not get "shafted" by business deals. Essentially, public managers have an ethical duty to be trained well enough to make better deals with private business for services, all the while keeping the public interest in mind. The very essence of the private sector is to make money, and whether or not an agency is inept at dealing with them should be of little ethical concern, since business's bottom line is to make money. The public manager must take into regards the citizens he/she represents, the competency level of his/her training, and personal ethics.

The public interest can be difficult to define, but can be seen or thought of as the overall good for the public. This can include concepts from justice and equity, to fiscal responsibility for tax payer dollars. But this all can be concluded that the public administrator owes his/her alliance to all citizens. The difficulty can occur when trying to balance legal ramifications, public interest, professional standards, organizational goals and personal interests. (Van Wart 1996)

Problems of privatization occur when corporations obtain monopolies over an area or service such as toll roads or the use of parking meters. In the examples of toll roads, corporations can contract for guaranteed price increases, implement their own businesses along a certain passage of highway, and maintain monopolies that last up to a century. (Baxandall, Wohlschlegel and Dutzik 2009) This can also be part of closed contract negotiations that do not allow public bidding systems. In many instances of 
privatization, contracting for certain services gives the winning bidder a chance at a contract that can be 50,75 or even 100 year length.

This thesis contends that the need of ethical competence of the public administrator is at all time high due to the increased usage of privatization between government and non-governmental entities. With these partnerships, the public administrator must act as a steward for the people in determining efficiency and reducing waste by being competent in contract negotiation, oversight and dealings. In many of the case studies provided, a clear need exists to have more regulations in favor of the public interest. A public administrator guards the public interest. It is her job to ensure the public interest and trust by being stewards of the people's best interest. While the privatization of services might be in the public's best interest, making sure that a manager is well trained in contract negotiations, financial responsibility, and open door policies remain the key point in making sure privatization goes well.

Corporations have only a responsibility to their shareholders and stockholders. While obviously bad public relations would hurt the company, the bottom line is the company exists to make profits. A public administrator's main focus is the well being of the public and the management of government. Not that privatization is a bad thing; it is when governments are taken advantage of and make poor deals, that the public is hurt.

When corporations take long term monopolies over services, they take power out of the citizen's hands. When informal bidding systems exist that do not allow for public bidding, the power of the free market is taken out of play. When inept public managers do not understand the contracts that are being negotiated due to inexperience or lack of 
education, they let the entire public down by not obtaining the best and most equitable deal possible.

What is the answer? 1) Better ethical training to ensure our public managers are more equipped to deal with these pitfalls, 2) Better education to deal with business practices that can become foreign while working in the government sphere, 3) Ethical review boards to ensure that moral lines have not been crossed, 4) Ethical review boards that have oversight to projects specifically dealing with privatization.

This paper does not seek to define ethics in personal or organizational methods, but takes a broader approach that seeks to input a better system for ethics to be permitted. It defines ethics from the perspective of obligations to promote the public interest. The public interest for a public manager can be ensuring equity in a contract such as fair dealings and fiscal responsibility for tax payer dollars.

There must be a calling for better accountability in privatization. In many of the case studies presented, the studies show instances where governments have entered into bad dealings with corporations in return for privatization of services.

This requires better competency testing of public administrators and ethical boards to measure the public interest. There must be specific oversight dealing with privatization and public reviews of the contracts. 


\section{PRIOR PRIVATIZATION STUDIES}

As the political climate shifts more and more in American culture, so does the dynamic of how government does business. Government agencies seek to transfer services to private companies in order to save money and increase efficiency. One specific area of this privatization deals with how government pays for these services and their true costs.

Obviously, roads are essential, but some major questions and issues become apparent when discussing ownership of services. All one needs to do is take a closer look at examples of privatization. A real question exists: How does government pay for these services such as roads, health care, prisons, or utilities?

Levinson (2005) seeks to answer that question citing various issues that can occur during privatization of toll roads. Levinson claims roads need to be classified for the specific purpose of providing access to land and function of movement. With this, the author states there are three plausible ways that presently exist to pay for roads: 1) direct tax, 2) indirect tax, which are both publicly funded, or there is 3) privatization. With tariffs, this assumes roads are public facilities because of tax collection; however not in all cases should they be public. Direct taxes can be burdensome for the public interest, and indirect taxes can make other non related goods increase in price. Privatization lets the fiscal burden fall onto the private company, with the company receiving incentives such as long term monopolies of controlled highway areas. 
Citing various studies, Levinson recounts the history of major highway expansion and shows how other countries and states look at road costs. Citing a history of developers for road improvement shows how roads were built and for what purposes.

The author concludes that, while a variety of techniques have been used to help pay for roads, ultimately toll roads help pay for the construction and repair of roads, despite the costs they incur. Levinson states roads need to be viewed in the same respect as public utilities, which allow cost fixing and use price discrimination to differentiate users by willingness to pay. The author claims that the way Americans view roads needs to be seen as less a right, but more a market good that costs for use. The author cites problems with monopolies could arise, but that toll roads maximize benefit for both government and private industry.

Levinson made claims about how roads are paid for as, well as what methods are presently available for funding and concluded that privatization was a viable way to conduct road building. Robert Poole (1997) presents contract management, long term franchising and divestiture as possible ways for long term private models to be used. Though the data is about 15 years old, the article does help lay the groundwork for how to think about government privatization.

Poole cites various studies to first make the claim that government services and transportation infrastructure is very inefficient and does not operate at maximum effectiveness. Using the World Bank model, the author suggests five approaches for improving infrastructure: manage as a business, introduce competition, ensure stakeholder involvement, make use of private public partnerships, and shift the role of 
government from provider to regulator. By managing the partnership as a business, greater detail to fiscal responsibilities can be had by the government. Competition helps lower prices and makes the market competitive and involvement from citizens and stakeholders helps with accountability of the public officials and that stakeholder's needs are represented. Making use of private partnerships means using the partnership to help lower the cost and increase the efficiency of government. Lastly, government should act as a regulator to ensure equity is met and that the partner of the contract is upholding itself to the terms of the contract and the law.

Poole cites three models of privatization as contract management, long term franchise, or divestiture which is long-term sale of government assets. Showing where this has been done to airports, the author claims this could work best for highways and roads. The author claims contracting out for toll roads would work best for the USA, however, divestiture, or selling off interests, might not be the best option. When the government sells off its interest in certain areas, the long term loss can outweigh the short term gain.

The author concludes that corporate monopolies of toll roads does not need to exist and privatization of roads can occur in much the same fashion as telecommunications, setting forth the way for private companies to come in and pay for privileges of operation.

Robert Stein (1993) seeks to also measure the level of effectiveness in privatization of public services. Defining service arrangements and making the way governments arrange for delivery of their service responsibilities should become a 
function of the scope and content of their service responsibilities. By examining these functions, the relationship can show whether or not the service agreement is efficient.

Using various economic models, Stein defines the role of municipal government as government substituting itself for other vendors and shows how government alters the relationship between private markets and consumers. Stein offers methods of payment through subsidies, vouchers and monies as means to pay for services.

The author points to a decline in municipal services and shows a narrowing scope, meaning more chances for privatization. In defining what constitutes service, Stein lays out the method of arranging city services. The author concludes that non- direct services increase the scope of municipal governments and the service model adopted by cities actually runs a potential threat of costing the cities money. Ultimately, the service defined needs to be based on function, meaning the function needs to be within the proper scope of what government can be or should be doing.

One thing to note, while the author did propose how to define and arrange city services, the author has left out many questions that other authors seem to hit upon, such as if a service is needed, how do we ensure fairness and competition when offering it. Stein also does not cover efficiency, but rather just scope. Efficiency helps define the cost of public services. Since most public/private ventures are done in the name of efficiency, this would have been helpful.

The Commission on Government Forecasting and Accountability Report (2011) shows some of the advantages of privatization. The report claims cost reduction, risk transfer, revenue sources, quality of services, expertise, timeliness, and flexibility are all 
reasons for privatization. Citing toll roads, utilities, prisons, government services, lotteries, and utilities as main areas for privatization, the report shows some areas of connection with public employees, transparency, ownership, competition and the importance of the contract.

The report states public employees often oppose privatization, because wages are lowered, benefits are cut, and jobs are lost. Transparency can be lost because little oversight is required. The idea of ownership becomes askew in which area of government owns the lease and who receives the funding due to lack of clarity in lease ownership and funding requirements. Competition can be scarce as often the contracts are long term and few bidding systems exist. The contract becomes highly important in dealing with cost and efficiency and ensuring a fair deal for the public.

The United States General Accounting Office, (GAO 1997) reports on privatization of social services, claims that from 1993 to $1997,80 \%$ of state social services departments had expanded privatization of social services. The report states this was done based on public managers, who felt they were reacting to the increased belief that privatization can provide better care, more options, and cheaper rates. Also, some private entities possess more expertise in dealing with certain issues than government.

The report states that challenges occur within the competition model of bidding for privatization of services. Secondly, many public managers have little training in contract negotiations of this type and monitoring progress can be overlooked. These issues could undermine the goals of efficiency for providing privatization by costing 
more resources than originally planned, especially if the market is not competitive enough.

The report finds mixed results in regard to improvement in services. In some cases, benefits are extended, in others, where no competition or oversight exist, privatization can cost more than if privatization had not occurred in the first place. However, GAO foretells that privatization will continue, but better program results are needed. The closed market system can become a huge landmine when dealing with the pitfalls of privatization.

Swinging a little bit more towards opening markets up and the problems with closed contracting systems, the next article shows how contracting solely with non-profits can stifle markets. This relates to problems occurring with any public utility source when little to no competition exists. (Smith and Smyth 1996)

Using North Carolina as a research point, Smith and Smyth (1996) state contracting out substance abuse services may hinder public competition for services and leads to devolution of services. The authors attempt to make policy recommendations suggesting opening non-profit services to compete for contracts for services to help create a sense of community. Devolution requires active government participation.

Citing North Carolina studies, the authors maintain the premise that little competition exists when contracting out stems from long standing relationships. Little innovation occurs. The authors deviate from the traditional argument that contracting out is based in the pursuit of lowering cost and improving quality. However, this only works in a perfect model. The authors claim doing business with non-profits help reduce 
transaction cost over time as government can cut funding and increase discretion. This stale contract setting in decentralized markets will be unlikely to evolve to keep up with needs of citizens.

The authors conclude that the absence of competition in the market stifles services and creates a lack of accountability. Claiming more formal and informal competition arenas need to exist, the authors state that government needs to reexamine its goals and the way it does business with services and become more market driven. The authors call for the government to be more market driven in where it spends its money and be more open to newer markets.

So what is the answer to most of these problems of monopolies besides a few policy recommendations? Cohen (2001) seeks to develop an approach to set up a framework on how a privatization function should be carried out by government with a heavy focus on the role of public managers.

By starting off with other scholars' research, Cohen (2001) identifies government motives for privatization as efficiency, less regulation and political pressure. He notes that government managers lose some control vis-a-vis private managers when privatization occurs. By separating characteristics of public and private administration, the author states environmental, organization, and internal structural processes are more complex when dealing with each organization with government managers losing some control versus private managers due to the common themes of why privatization can be viewed as better. By making these distinctions, public managers can better perform duties. 
Cohen (2001) suggests government is best suited for police and regulatory actions and, thus, would be better off to perform these types of functions than the private sector. He also adds that public managers are better at helping people that are not customers, such as non-profit clients.

Cohen concludes the decision to privatize is contextual and should be based on function first. Policing and regulation should be done by government, but pay for services should be carried out by private service providers. The author designs list of contextual questions to help guide the public manager that includes program goals, risk, assessment, financials, and impact to name a few. He states these aspects must be considered and a strategic approach to privatization must be used which requires ethical, political, economic and technical decisions.

Furthering the approach to how governments should privatize, Ghere (2001) maintains the goal of his article is to not to debate the pluses and minuses of privatization, but to uncover some of the techniques used in privatization. Ghere discusses four aspects of privatization: 1) choices, 2) interdependence, 3) imperfect information and 4) chance. Choices allow privatization to be more efficient by opening up markets to increase competition. Interdependence is where both entities can gain equity. However, because perfect information does not exist, it can be easy to fall into unequal contracts. Chance can mean knowing the right person, or being the right bidder for an opportunity or the state uncovers a need for service that had not been there previously. 
Much of the author's methodology comes from first hand observation. Uniquely however, the author uses a patent metaphor to show the techniques of privatization. The author claims both patent and private partnerships trigger entrepreneurial activity and each incorporates specific strategies. While the author's methodology could be interpreted differently if the information was used by different authors it does bring up an interesting way to think about dealing with government contracts.

By comparing ownership ideas of patent versus partnership agreements, it is often a third party or person who knows how the situation works that deals with a company's property rights and interprets what rights are maintained by the private partnership. The author also compares how disputes are settled and then moves into strategic issues of the public/private partnership, specifically the strategy of contracting out. Since the partnership has to deal with ownership rights of work, contracts must be more sophisticated, "facilitating asset creation for private interests." (Ghere 2001)

The author goes on to show the relationship between patent ownership and private public partnership. There is often an ambiguous right to ownership with patents expiring and becoming public. Often in the private transition, the private company might own intellectual property rights, but after a certain time, it does come back to the public sector.

The author then goes into what he calls implications for public managers. He claims a shift needs to occur to achieve better contract negotiations, where public officials become the "gate keepers" for entrance to the public "intuitional rock" (Ghere 2001) and keep the contract about public interest. Rather than just being a "smart buyer," public managers need to focus on possible policy concerns and long term policy effects. 
Last, the manager needs to take a leadership role in the negotiations and process rather than just relying on the private sector. The author concludes that the patent metaphor is apt for the private sector and states that managers need to be aware of policy and political concerns and keep the public interest in mind.

Wayne Cameron (2004) looks at ways government can be held more accountable for its actions. By defining accountability as giving explanations to citizens, open scope of records, review systems and the ability to grant redress or sanctions, Cameron (2004) states that public accountability is the most import characteristic of modern democratic government.

The author claims ethical performance is the principal mean for determining accountability within government. By becoming transparent, ethical conduct and decision making can be overseen and performance can improve.

Cameron acknowledges stricter standards are applied to the public sector than anywhere else, but that government has many resources and therefore must be ethical or lose the public trust. He claims performance reporting is one of the best ways to show accountability.

Moving on with the same sense of privatization, the authors of the next book take a wider approach to privatization by looking at different models of road privatization from Mexico, France, Spain, USA and other small developing countries. While the previous author concludes the privatization model is a success, the authors of this book are not so sure. (Gomez-Ibanez and Meyer 1993) 
The authors cite the idea of efficiency could be a mistake, as public agencies can tap private markets by issuing bonds just as private firm would. The authors make the claim that with efficiency, there are winners and losers. If a private company contracts out service, they could pay lower wages and employees do worse as a whole, thus affecting society negatively. Also, there can be environmental concerns as well.

Looking at studies from various countries, the authors' methodology seems very thorough. First looking at bus transit routes, the authors explore toll roads in France and Spain. Spain has built half its roadways through privatization and France uses more toll roads and shows little cost towards the government. France has shown that private companies can produce roads more efficiently and cost effectively, but questions remain about whether or not they can maintain them to elevated standards in the long term.

In their article, Baxandall, Wohlschlegel and Dutzik (2009) argue that the extended length of most toll concessions makes it difficult, at best, to make accurate predictions about environmental changes that will undoubtedly occur over the life of the contract. Therefore, the provisions of the contract should be subject to change. However, it contradicts contract management. It can sometimes be the best practice to leave much room for discretion within a contract and the only other alternative would be to engage in expensive litigation to renegotiate. When dealing with a contract that spans half a century or more, repeated costly renegotiations would be necessary. For this reason, both France and Spain require toll contracts be renegotiated every 7.5 years.

In the US, toll roads began to see more thought and prominence in the 1980's due to costs of old road repair and a stalling economy. Citing Virginia and California as the 
largest areas for toll roads (Gomez-Ibanez and Meyer 1993), some claims are made that tolls can cover all costs of roads; however few actually do this and most rely on government subsidies. The authors do show that monopoly of services and regulation can cause problems. The authors fail to make a conclusion on whether or not the toll roads are better; however, they do think the innovation from private companies should help this problem.

The authors really lay a lot of groundwork for studying privatization, especially dealing with toll roads. Cited by multiple authors, this book helps understand many of the problems that other scholars miss. These ideas become central tenets when thinking about effectiveness, efficiency and how to pay for the costs of roads, even warning to be careful of myths that can come about from this study (Gomez-Ibanez and Meyer 1993).

David M. Van Slyke (2003) takes the concept further in his article, "The Mythology of Privatization in Contracting for Social Services." Van Slyke claims competition does not always exist and certain ideas are myths when talking about privatization such as efficiency and effectiveness.

The author begins by tracing the route of privatization showing how it has gone from state level of thinking to a privatization model, thus downsizing the government. Van Slyke (2003) shows many social services had been contracted out. In this intensive study of empirical data the author shows how privatization reduced public management capacity, non-profit relationships were hurt before the state level and last, the non-profit relationship was restricted from entering a privatization market. This leads to the author's contention that there is little completion for services and privatization is not efficient. 
The author shows competitiveness for new privatization services was limited to new parties and this handcuffed non-profits from being able to compete with private companies for services. This leads to problems such as lack of funds for current nonprofits and loss of expertise in certain areas, especially social services.

The author concludes that a myth exists where services are opened up for competition. This is rarely the case and often times privatization benefits occur outside of competitive levels. This in effect, short changes public manager's abilities to act as smart buyers when shopping out services, because they literally feel the effects of the lack of competition. The author's research using a famous New York study shows, that monopolies can exist and cuts out much of the public sector as an unseen cost of privatization.

The next article by Spry and Crowley (2004) attack a more specific problem associated with monopolies. The base premise of privatization revolves around the idea that open contracts make the market value of goods and services cheaper and more efficient. The authors maintain that instead of this open bidding occurring, a more monopolized system is actually in play.

Using economic theory of monopolies and an economic model, the authors show how a monopoly is created within the toll road system based on gasoline, food products and the service areas. Citing New Jersey rest stop areas solely operated by private toll road areas, the author's methodology shows cost of average goods remains higher in these areas than standard pricing. The authors use data from food service to show that the cost of small general goods, gasoline, and candy were higher in all conditions. 
Conducting a curve model after conclusions of showing that a monopoly exists, the authors show the total loss in consumer welfare versus the specific goods. Using the Lerner Index to show case monopoly price strategies, the authors contend social welfare is being sacrificed due to price exclusivity and rent seeking.

Using economic models really helps readers understand the implications of the authors' article. The authors conclude consumers are clearly weary of toll roads and recommend three policy changes. Open contracts up to more firms, open more competitive service areas within the toll road structure and open up advertising to non toll road companies. While the information is based on economic models, it should be noted that the authors did fail to compare the overall cost to society when governments build the roads, effectively leaving out a better alternative.

The author's examination of privatized ports in England helps to understand how to look at privatization in a world context and how it affects society as a whole. Ports act as toll roads and while different, have many congruent similarities. (Baird 2000)

While the seaport model is different because of a more regulatory body watching such as the port authority, the system is contracted out to a private system, but has more government controls upon it. The author takes the concept of privatization and places it into three parts: Regulator, Landowner and Operator. (Baird 2000) The model supposes an all public ownership all the way to an all private ownership with almost no government involvement, placing all responsibility on the private company.

The author uses studies to show that privatization can be more globally efficient as ports are needed for trade. Privatization reduces demands on the public sector budget 
and reduces cost for governments. The author claims this is also good for the public sector, as the private sector can raise more revenue and operate more efficiently than the public.

The author concludes that $90 \%$ of the port authority partnerships have moved to a private model, and illustrates that the growing trend follows through with his theories of growth and revenue.

The research shows that many problems exist when dealing with government privatization. Whether or not privatization is a good thing is not necessarily concluded, but if fair play exists, open markets, apt public managers and funding sources, privatization can help governments pay for a basic utility. Much consideration must be given to dealing with how to proceed with the true costs of privatization and the information provided here can help officials make more informed decisions.

Sometimes, public outcry becomes so potent, that changes in privatization must occur. In Koven and Lyon's (2012) book on economic development, the authors look at ways government can increase economic development. In one case study, the authors cite opposition to the I-69 toll road in Indiana. The state was planning on a toll road, however, environmental groups and citizens filed a law suit and claimed the government had rigged the environmental studies and the roadway would be harmful to the environment and area. While the lawsuit failed, public opposition held and the plan was scraped. Koven and Lyons (2012) point out privatization is becoming more and more popular with states, and credits Wall Street for the increase in popularity. In other state deals such as the Chicago Skyway, Goldman Sachs received a deal that included nine 
million in fees for the bank. In Texas, an Australian toll road builder paid over one billion dollars for a ninety-nine year lease.

In a more striking case of privatization gone awry for the public, Chicago sold its rights to parking meters to Morgan Stanley, a large investment bank. Morgan Stanley paid Chicago over one billion dollars for a seventy-five year lease. Morgan Stanly then simply raised the meter rate four hundred percent. It was discovered the city could have collected $\$ 2.2$ billion had it simply raised rates by the same amount. On top of the loss, if changes in roadways were to occur where meters are located, the city of Chicago would have to compensate Morgan Stanley for lost revenue.

Koven (2008) establishes a framework for thinking about ethics using case studies to illustrate unethical behavior. In his book Koven uses case studies to show where government has gone wrong. He cites scandals from money and politics to the misuse of funds dealing with Katrina. What is important to note is that Koven asks the reader to take these historical case studies and apply them to critical review of ethics into our system's framework. He sets a guide for how to think about ethics. Citing history, laws, and mores, Koven states, "Responsible governance must advance democratic values through ethical behavior." (Koven 2008, 171) This remains highly important for the public administrator, since they are the ones acting out the governance of our society. Most notably, Koven addresses the idea of public interest and the role the administrator must take in protecting that interest claiming the administrator must look at the different subcultures our shared ethics come from in dealing with public interest. 
Koven $(2008,27)$ breaks down conceptions of public interest into 7 parts: 1$)$ People hold the belief that people know their own interests and can check abusive power, 2) People believe that representatives of the government must act in the interests of the people, 3) Belief that the autonomy and improvability of the common man can lead to a good society with concern for the public interest, 4) A belief in a common good that directs public officials to faithfully execute the will of the people (Rationalist view), 5) Belief in a higher natural law through a voice of conscience (Idealist view), 6) Belief in the public interest defined as a resolution of conflicting claims of interest groups (Realist view), 7) belief that the public interest is enhanced through active citizenship. While the public interest can be defined differently by which philosophical view point one holds, it holds that a greater need other than oneself exists for the public official to put public needs above personal needs. The scope can be very broad, but the public's welfare is paramount.

One of the biggest questions answered in the literature review, has to come from Terry Cooper. (1998) In his publication, the Responsible Administrator, Cooper looks at the dichotomy between the individual administrator and the organization. One of his main claims deals with responsibility and how this concept falls on the shoulders of the public administrator.

Starting off, Cooper gives us ethical dilemmas to show that ethical decisions are not always clear cut. Many levels exist in order for the administrator to do the right thing. Cooper advocates a decision making model, that guides the administrator through a process, in order to determine the correct decision making process. 
The process of ethical oversight for the public administrator boils down to two options: the subjective and objective roles. These roles help determine the conflict for the administrator when dealing with ethical dilemmas. For the organization approach, the internal and external controls apply. This relates to an organization's control over ethical oversight and eternal committees or organizations that overlook the agency.

Cooper's ethical decision making model helps the public agent work through ethical problems by using a framework in which to analyze the problem. The model contains 5 parts: 1) Perception of an ethical problem, 2) Defining the ethical issue, 3) Identifying alternatives, 4) Projecting possible consequences by using moral rules, ethical principles, defenses of the stance and self appraisal and, then selecting an alternative. The last, 5) is a state of resolution to the problem.

The model is not perfect but acts as a starting ground and a way to process the information. In order to begin, the public administrator must know a possible ethical problem exists. Since this thesis uses privatization, the model can be seen at looking at possible contract transaction between public and private entities. By describing the situation, the public administrator can define the ethical issue. In some instances, the ethical issue can be whether the contract is in the public's best interest. Cooper uses hypothetical scenarios throughout his book to help process this type of information. For this paper's purposes, a broad example can be used. After deciding whether or not the contract maintains equity for the people in terms of being fiscally sound, the public administrator must decide alternatives. In the Chicago parking meter case study mentioned previously (Koven 2010, 148), the city lost out on a billion dollars of income. In that situation, the contract was not sound, as it sacrificed long term loss for short term 
gains. The lost revenue could have been used more appropriately for the public good. In that situation, alternatives could have been a public bidding contract or adjusting the parking meter rates as a municipality versus a partnership.

The moral and ethical concerns must be addressed in this model, with a solution that can be justified by the model. In the Chicago model of parking meters, it is unknown what ethical standards were used, but it can be assumed that the contract was made based, partly, on the city's need to have immediate services fixed and at the time, a sacrifice of long term was warranted in the public administrator's decision.

The model Cooper proposes helps the administrator deal with all of the ethical conflicts the administrator must deal with in deciding what is best for each role she plays. The model helps resolve those tensions and at least give thought on how to proceed, in which many times, the answers are not clear cut or apparent. Cooper gives the reader a framework in which to answer these tough questions. The framework uses an input and output model to arrive at decisions.

James Bowman (2009) takes it a step further claiming public administration "is justified by moral purpose." Dividing ethical competency into three parts, need, looks and role of establishing competencies becomes Bowman's high priorities.

The idea of need for competency looks at the world market today and specifically the US in the markets in 2008-2009. Because of the downturns many governmental departments are looking for better ways at being efficient. Like Cooper, Bowman stresses the need for an ethical competency framework for public administrators. Bowman 
suggests adding ethical competency into all classes and have ethics be brought to the forethought of discussion.

Bowman starts by quoting Dennis Thompson's famous paradox, "because other issues are more important than ethics, ethics is more important than any issue." (Bowman 2009, 1) From this quote, he claims it is the hallmark of good government. Bowman claims the need for ethical competency is greater now because of the merging private public partnerships and the public administrator's duty is to protect the public interest. The look of ethical competency is defined by Bowman as creating standards that identify performance factors, more defined parameters, and creating higher skill sets in dealing with ethical competency, such as review and regulatory boards. The role of ethical competency should be placed above all other issues and training to ensure better protection of the public interest.

Montgomery van Wart (1996) helps with some background for the ethical code that was submitted by The American Society for Public Administration (ASPA). The author shows that for many years, the code of ethics for public administration was somewhat confusing. By creating a new framework, the code is supposed to be more authoritative on the matter of ethics.

The author discussed five concepts to help the code of ethics were; 1) Public Interest, 2) Legal Interest, 3) Personal Interest, 4) Organizational Interest and, 5) Professional Interest. Public interest means serving the public beyond serving oneself. It can mean putting equity, social justice and fairness on par or above business. While not defined as well as it could be, public interest is one of the main concerns in dealing with 
ethics and becomes more definable as a population becomes more defined. What works in one area, might not work in another.

Legal interest is defined as adhering to the law of the land and the regulations. Van Wart (1996) goes on to say that many consider legal interest as the baseline for ethical behavior. Van Wart thinks it should be expanded past legal obligation, to moral obligation. Personal interest is defined by Van Wart as personal values a public manager must hold from honesty, consistency, coherence and reciprocity towards other individuals. Organizational interests must play a huge part by being productive, ethical and experts in their field. Lastly, professional interests are a little harder to define, but relate to the standards of the field itself and the standards it sets. By creating higher ethical standards, the professional interest can ensure the public interest is being safeguarded. 


\section{ASSESSING PROCEDURES AND IMPACTS OF PRIVATIZATION}

The literature shows examples of the how and the where of privatization, with some showing the effects. The literature gives nice case examples of where privatization has occurred and some of the problems associated with it. The ethical framework helps administrators decide on how to move forward and best help the public interest.

Privatization can be a good thing and should be a good thing. Sometimes, government needs to contract services out to private sector. That being stated, there must be some kind of oversight for the public administrator. The main goal of business is to make profit. A company makes profits, and then they can continue doing business. The public administrator must think about more than this. She must think about people, how it affects them, the money spent, and the business partner. However, as Long points out, the primary ethical concern must always be about the public and how the action will affect the people. (Long 1988)

As more functions of government are privatized in order to provide service, many questions are raised on the true cost of privatization and how it affects equity, hidden costs and the development of monopolies. Creating a monopoly system with a private company being the only provider for a necessary service for extended lengths of time can cause many problems. Long examines various causes and facets of monopolization, who 
carries the cost of when a company receives subsidies for providing services and seeks to determine whether private roads truly serve the public interest. Equity must be addressed so that cases such as Halliburton obtaining no-bid contracts with no oversight do not occur again. In that case, there was no equity, and the government overpaid. (Berrios 2006)

This investigation begins with a look at soliciting and initializing contracts. (Long 1988) Many times when initializing project partnerships or renewing contracts, good managerial practices are not followed. Rather, informal connections are used to create a contract instead of a formal bidding system. Some states even receive unsolicited proposals and officials are lobbied to consider privatization. In the event that a formal bidding system is used, it often discourages outside competitors from bidding for the project and will often times put relevant public entities at a disadvantage.

While many favor privatization as a way to help cities pay for roads, keep budgets on target and taxes low, a darker side exists that is not necessarily advertised to the public. Granted all things have a negative side, however, what must be determined is whether the disadvantages of privatizing outweigh the benefits?

For example, the privatization of toll roads is viewed as a way to both make money and save money. For the government, it is a method of achieving efficiency and cost benefits. In this, the private sector is seen as being able to better control cost and maintains the roads more effectively than government. As roads are built and financed by private companies, government capital costs are lowered, which allows officials to avoid raising taxes to fund development of infrastructure. For private companies, tolls are seen 
as a low risk investment with almost guaranteed profits. However, problems arise when there is a lack of competition among potential service providers. If informal channels for soliciting vendors are used instead of open bidding, there is no incentive for the service provider to include competitive features or offer additional benefits when presenting a project proposal. This can also incline private companies to behave opportunistically and attempt to control a monopoly of services, thus creating higher prices for consumers.

Additionally, inadequate contract negotiation, management and oversight by the government can result in costs that are ultimately passed on to citizens, or worse, overlook the public interest altogether. Ineffectively negotiated contracts can include provisions that protect the interest of the service provider and its profit over the government or the interest of its citizens. The length of many privatized contracts alone predisposes the situation to a monopolistic structure.

Using descriptive analysis from other works, the research in American privatization identifies problems based on monopolies, closed bidding systems, lack of effective government management and loss of public control. This in turn creates inefficiencies for government and its citizens. When closed bidding systems occur, prices are not competitive and thus companies can name their own prices once these monopolies are in place. In various studies, vendors on toll roads charged much more for goods such as gasoline and food products than those found on un-tolled roads. (Spry and Crowley 2004)

Some of the data in the research displays how problems occur due to lack of formal bidding and lack of trained public managers in negotiation. This also factors into 
the creation of inefficient monopolies and can create incentives for private companies to create monopolies. This can be seen in places such as New Jersey, Chicago, Virginia, and California where monopolies have been created. (Gomez-Ibanez and Meyer 1993)

Spry and Crowley $(2004,394)$ identify pricing advantages in monopolies, "beginning with Hotelling's seminal contribution, the spatial pricing literature has considered the effects of transportation costs, or product differentiation, on firms' pricing decisions. Toll road service areas are able to charge noncompetitive prices because of the combination of the legal barriers to entry of competitors along the toll road and the transportation costs consumers face to buy goods off the toll road."

Essentially, because toll roads have an exclusive right to the area and land, they can then control privately regulated monopolies. The issue is this: since the state contracted this service out to the private company, the government must accept responsibility for fostering a monopoly. By using a linear economic model, goods can be compared by taking the price of goods at a select service area on the monopolized toll road with the price of goods at an exit point. By comparing statistics with a demand curve for both points, price mark up can be directly related to transportation cost. This also creates an incentive for toll road service providers to reduce information about alternative venders.

Spry and Crowley (2004) claim a social waste is created because the incentive to become a monopoly is so high that companies will actively engage in seeking this type of behavior. The waste comes about because all goals for the company that are not related to service go into ensuring the monopoly. 
One rebuttal is that price caps exist on these toll road areas; however usually no incentive exists to enforce these caps because of exclusivity The New Jersey Turnpike granted exclusive rights to HMS Host to sell goods such as gas and food until 2021. (Spry and Crowley 2004) The other aspect of incentive is lost due to no competitive bidding. The contract for the Turnpike was renegotiated in 2000 and 2001, yet no formal system was in play to open it up to other companies. By not offering public bidding, cost was higher and the public was forced to pay more because of the monopoly. No other company was able to come into the negotiations and try to lower the cost for the public.

Overall, HMS Host charged about $27 \%$ above market value in their region of New Jersey. (Spry and Crowley 2004) From the data, the government has essentially created a monopoly for the toll road company and thus created inefficiency. Here, little equity exists for the public. The public must pay higher prices and no competition is present to help lower pricing.

Another question to consider is what happens when private entities fail? Who is expected to assume responsibility? There are numerous examples of failed private infrastructure projects throughout Mexico, Indonesia, Hungary and Thailand that have had to be reclaimed by the government as a result of default or bankruptcy by the private provider (Baxandall, Dutzik and Wohlschlegel 2009) Again, adequate provisions should have been included in the contract that safeguards against such situations or more care should have been exercised in selection of the contractor. If the government assumes operational and financial responsibility of the road, costs will presumably be recouped from citizens in the form of increased tolls or taxes. 
Gomez- Ibanez and Meyer (1993) cited cases in California and Virginia where companies received government subsidies and essentially maintained a monopoly for those regions. In this, the authors found that these companies also never underwent a formal public bidding system. Additionally, because the companies under calculated traffic patterns and business, the companies actually received subsidies for their own miscalculations. These calculations helped these companies receive money from the government and raise prices on consumers.

It should be noted, that the Gomez-Ibanez and Meyer (1993) actually contend that in France, where most of the toll roads were built by private businesses, efficiencies exist because of prescribed concerns. They cite five basic lessons. First, competition is highly desirable if privatization is going to work. Second, the private sector can be more efficient in a place where the public sector does not have the means or efficiency to do so. Third, competition is better when fewer political infractions exist. Fourth, privatization works better when few controversies exist such as environmental or general opposition to economic growth. Last, the authors conclude privatization works when the government does not need to subsidize the private industry. They found that few of these factors actually existed when looking over the facts of their case studies.

Van Slyke (2003) contends that in New York, when scouring data showcasing private/public partnerships, only one out five counties actually used a public bidding. This type of closed practice leads directly to the observation that good management practices are not followed by not formally opening up the bidding system. It is generally agreed upon that competition helps lower prices and helps stimulate efficiency. 
Additionally, systematic approaches must be built to evaluate the impact of privatization on the public interest and develop criteria by which to judge proposals, prior to ever even soliciting bids. Baxandall, Dutzik and Wohlschlegel (2009) discuss how both Australia and Britain have implemented effective models of systematic evaluation. Important factors are identified and turned into a rubric with which to score the benefits of potential deals. However, this tactic has not been widely adopted in US practices. New Jersey, Pennsylvania and Illinois have all admitted that this kind of system was not utilized to assess public interest concerns when planning their toll road concessions. Furthermore, not only were public interest concerns ignored, but very little public participation was encouraged. Both the Chicago Skyway and the Indiana toll road deals were completed with very little public participation or input. 


\section{ETHICAL CONCERNS IN PRIVATIZATION}

By looking at New Jersey, New York, California and Virginia each state maintained an informal bidding system, created monopolies for the companies, and then encountered unforeseen costs that created inefficiency among privatization and the contracts. These findings show that by allowing such actions, inefficiency and inequity are frequent results of this privatization model (Gomez-Ibanez and Meyer 1993).

The findings show that privatization can work, but only when un-subsidized and when there is a desirable level of competition. In cases of California, Virginia, New Jersey and New York, closed bidding systems without competition were prevalent in the contracting process (Gomez-Ibanez and Meyer 1993). This effect cost consumers in the form of higher prices, increased tolls and government subsidies.

Stein (1993) believes that if effective models are introduced into the full procedure of bidding and contracting out, this can make efficiency more pervasive. He claims that a company would act as a franchise and be a part of the regulatory power of government. With this type of model, greater transparency and accountability in the process can help reduce the negative effects from the bidding system and allow toll road services be delivered at a lower price. 
The goal is to retain public control, create clearer contracts and better systems of oversight for public managers. This increase in efficiency will result in better prices for consumers and the government entities creating these contracts will be able to be held accountable for the results of the deal.

Taking this concept a little further, Cohen (2001) thinks many of the problems of inefficiency can be solved by separating functions into 3 factors: 1) Environmental, which appropriates resources more effectively, 2) Organization transactions, where government should use more leverage to create better deals, and 3) Internal structure, which helps government become better trained at dealing with this problem. Unfortunately part of the problem could be solved if public managers had better contracting skills and used them appropriately, similar to a business model.

This is where ethics of competency come into play. Not only does the public administrator need to be ethical in her decision making, she must have the correct and proper training to ensure an adequate and fair deal has been presented. As the GAO report (GAO 1997) shows, often times the public administrator is not well equipped in dealing with contract negotiations. Deals can become one sided and too many concessions are given to a more savvy business partner. Many companies gain much of their profits from dealing with government contracts.

Baxandall, Dutzik and Wohlschlegel (2009) concur that the problem lies within the terms of these concessions. Too often, because the private entity is more adept at negotiations, the provisions of the contract protect the provider rather than the public. This can be seen in examples of non-compete and compensation clauses. These clauses 
entitle the provider to remuneration if the government or transportation policy interferes with the profitability of the private project. Indiana was required to compensate or reimburse the toll operator, Macquarie Atlas Roads, for revenue lost when officials waived toll fees during evacuation after a state of emergency was issued due to flooding. (Baxandall, Dutzik and Wohlschlegel 2009)

Poole (1997) contends inefficiencies of government still are coming out with privatization. He claims there are a number of problems in what he calls the pork barrel problem, the free money problem, the non-pricing problem, ribbon cutting problem and innovation problem. Pork Barrel deals with the problem of choosing contracts over political criteria rather than economic criteria. The free money problem addresses grant levels of the subsidies, and the non-pricing problem looks at trying to take away exploitative pricing. All of these problems reduce efficiency, thus taking away incentives for efficiency. Ribbon cutting allows resources to be allocated away in order for politicians to be seen. The innovation problem deals with the high risk of innovation and losing out on money. Tolls are regressive taxes forced on commuters; privatization transforms public space into private space, shifts burdens on users, and enriches private companies, often foreign multinationals.

These problems combined show an incentive exists to create closed bidding systems and monopolies. When properly addressed, these problems can be cured to make privatization markets more efficient. The path to creating fair, more efficient privatization contracts remains open. However, contracting officials must first become aware of problems, address them prior to signing any deals, and include solutions and safeguards within the final contract. 
There are many obstacles to consider and hurdles to overcome in order to execute successful, efficient and equitable contracts of privatization. However, it is possible if the necessary factors are taken into consideration and essential precautions are observed. There are conditions under which privatization works. In other countries such as France and Spain, the models appear to work best for the public interest and private companies. Efficiency can occur, but the complications need to be acknowledged prior to privatizing and prevented through appropriate contract safeguards.

When a formal bidding system does not exist, monopolies result. Undoubtedly, the use of the competitive market model in privatization would increase efficiency of both execution and cost. This could also help ethically because it increases equity among partners of the privatization.

Most importantly, the public benefit as compared to the public cost should be systematically evaluated and contracts written accordingly. Concession agreements must equally uphold interest in both government efficiency and the public interest. Lengthy contracts spanning generations support the institution of monopolies through provision of subsidies and do not allow for necessary adaptation of practices in response to inevitable environmental changes over time. The agenda of the private company does not always support that of a state's long term service plan, so it is essential that contracts are constructed to align with both governmental and environmental goals. Reducing the length of contracts will promote constant reevaluation of circumstances and ensure that the state is receiving adequate compensation for its assets. Skillful drafting of terms for successful concessions will require government contract managers to be as adept at negotiations as their experienced private counterparts. 
Ghere (2001) claims partnerships are valuable and that by using game theory models, it can help elevate the process into a more mutual agreement. By assisting public managers in forming better concepts and recognizing strategies, efficiency can be more evenly distributed. In a sense, public managers need to learn from business models in order to be better able to contend with the more veteran private companies who are more seasoned in contract negotiations.

Also, the public interest comes into play in dealing with the workers and wages attached to the privatization. Corporations often pay lower wages for such contract services than the government would. This takes into account retirement and health care benefits. Many times, when privatization occurs, employees get a negative result.

Finally, the government must consider the true value of what a private corporation is offering and actually capable of doing. If the proposal contains significant outsourcing, perhaps states should consider outsourcing for individual services themselves instead of total project management as a way to retain control.

Equity remains one of the concepts that also must be considered in the contract negotiation and the ethics of the public manager. Equity can mean fiscal responsibility from the public manager, ensuring environmental rights, or fair play and justice have been met.

This all comes down to ethical oversight of the issues of privatization, from monopolies, to contract negations. What is the solution then to the problem? A few answers exist, but it requires more training, discipline and oversight from the public administration community. 
The Civil Service Reform Act of 1978 (CRSA 1978) sought to bring a higher level of ethical oversight to the federal government. Based off the atrocities of Watergate, Congress eliminated the Civil Service Commission and constructed the Office of Personnel Management, the Merit Systems Protection Board, and the Federal Relations Authority, all to regulate ethical behavior within the federal government limits. These three agencies all look at ethical oversight, but specifically they deal with human resources, collective bargaining agreements with employees, and discrimination, respectively.

While all the ethical oversight and compliance is needed, the problem is that the CRSA does not address how public administrators deal with private entities in terms of contract negotiations and privatization.

Cooper (2012) states that doing ethics takes more than just performing duties, but actually taking this a step further and thinking about the systems that are ingrained in our structure that deal with beliefs, values and principles. By taking a look at the social values, administrators can help better define what social roles they meet and must be thinking about. Cooper states objective reality can be thought of as externally imposed obligations. These come from legal, organizational, and society. The way a public administrator can truly understand ethics is by defining and understanding their social role. Often times, the public administrator in regards to privatization must play many different roles that incorporate all aspects.

No right answer exists, but some choices are clearly more wrong than others. Closing off public bidding systems, lining one's pockets with bribe money are the 
obvious wrongs. However, it is when the public administrator thinks about their role and their obligation to the public that true ethical behavior will be born. Long (1998) thinks the public administrator's primary ethical concern must be about the public and the how the action taken will affect the public.

Now some states have championed their own ethical commissions in order to try and guide public administrator's behavior. Kentucky has the Kentucky Legislative Ethics Commission and the Kentucky Executive Branch Ethics Commission.

The Executive Branch Ethics Commission helps regulate and establish standards of ethical conduct that oversees the entire Executive branch of government. While this is one step in helping regulate ethical behavior, it could do more. The agency itself is an independent agency that is supposed to promote ethical standards and increase public trust. The issue of it doing more comes from the fact it only regulates one branch of government and maintains a very limited scope. It does help educate and give guidance to employees and gives a means of reporting and investigating ethical violations. This can include everything from public spending, to enforcing provisions of the code. This is something that should be expanded to move beyond just the reach of the executive branch into all aspects of the state government from the law, organizations and society.

The Kentucky Legislative Ethics Commission uses the state legislative ethics laws to regulate a broader area of government employees from the conduct of the General Assembly, financial disclosures of the General Assembly and registration and statements of the General Assembly. 
Kentucky does maintain a code of ethics for its employees, however: The Kentucky Code of Ethics. It states the proper operation of democratic government requires that a public official be independent and impartial; that government policy and decisions be made through the established processes of government; that a public official not use public office to obtain private benefits; that a public official avoid action which creates the appearance of using public office to obtain a benefit; and that the public have confidence in the integrity of its government and public officials." (KRS 6.066)

This is a start in the right direction, but the problem is how improper benefits are aligned or discovered. By increasing the reach or oversight that these committees maintain or creating new boards, the reach can have all kinds of ethical implications. This can include greater ethical control of competency to decision making abilities. It can also help organizations know the framework in which they are supposed to carry out their mission in an ethical manner.

Cooper $(2012,131)$ states, "designing an organizational environment that is supportive of ethical conduct is a central ethical obligation of managers, one that becomes increasingly more important with the movement up the organizational hierarchy." This means that in order for correct ethical behavior to occur, the organization must empower the public manager to make correct ethical decisions. It must be at the forefront of every decision. When dealing with privatization, it is important to think about the internal and external responsibilities of the public manager. Externally, boards and ethic review committees must monitor the behavior and conduct of the public manager. 
Civil Service reform is only one step in ensuring that the public administrator is competent and ethical in their positions. While Kentucky has taken a lead in this, more needs to be done to ensure that privatization is effective and cost efficient for the public interest. This can include education, board for licensing and ethical review committees as part of the solution.

While more and more universities are offering courses in public administration, schooling must remain a high priority in dealing with this aspect for the public administrator. Schools and universities need to go outside the scope of just dealing with public administration, but add a facet that incorporates the private elements of business transactions so that public administrators can understand contract negotiations and private financing. By offering contract negotiation classes, business oriented mind sets help ensure fair dealing and protect the public with privatization. The required level of competency helps ensure ethical behavior at least on one facet of the solution.

Another alternative solution would be to issue licensing to public administrators. The licensing would ensure that public administrators meet a minimal standard by having training. This would work much like other professions have for doctors and lawyers. Each profession must be licensed in order to practice in their field.

By creating a national licensing board, it would also create the standard of review for issues specifically created by privatization. If a public administrator or group of administrators performed something questionable or routine, a federal, state, or local review board could ensure ethical standards have been met, and even make this requirement a part of contract negations. The cost of not having such board can result in 
higher tax burdens on average citizens as illustrated in the case of increased parking meter rates in Chicago. (Koven and Lyons 2012)

While this all can come off a bit cumbersome, from many of the instances presented above, privatization remains a hot button issue. The focus of privatization needs to be more than just ethics. It needs to also consider issues such as efficiency, equity, and scope of government.

While there will always be times that some entity gets the best of another entity, as public administrators, we must find ways to conduct good business by being competent and improve the lives of citizens.

Cameron $(2004,65)$ claims that "managers of tomorrow, will need increasingly to factor into their reform agenda time and opportunity for buy in and joint problem solving." This means that public mangers must begin making time for accountability. While this can all be taught in school and reviewed by boards, the public manager must also take into account all the changes that must occur in order to make ethical decision making. This will help with transparency of government and dealing with privatization by factoring in time to change and adapt to business practices. 


\section{CONCLUSION}

Public Administration has seen its evolution from a broad notion to a specific science, seeking ways to improve bureaucracy and administration within the public world. The field deals with many complex issues and ways to improve. The public administrator must be a good steward of the public interest. She must be trained in many different fields and skill sets. Privatization is one of those areas. Because of the problems that exist, the solutions to these problems have become more complicated and need to come to light. Exposing the inequities must be a high priority.

Case studies show that the public is not necessarily served through privatization. Short term gains may be achieved but longer term interests of citizens are sacrificed. Short term infusions of cash from multi-year leases of public land may be politically popular but can have wide ranging negative consequences, from monopolies in toll roads to social services. Many services are so important, that cost and efficiency, while important, might not be the primary idea behind them.

The modern impulse toward privatization is motivated by various perceived problems that it seeks to solve. The first is the supposed inefficiency of public enterprises due to the absence of the profit motive. The resources obtained by managers in the government sector may not be related to the revenues they generate, but to the 
importance of the service they deliver. The justification of costs is more important than the potential for revenues. In the private sector, operating resources and capital investments tend to be based on the potential for payout. By removing the relationship of revenues to expenditures, it is difficult to impose a downward pressure on costs, and therefore efficiency is not always rewarded." (Cohen 2001, 437)

Cohen warns us of the pitfalls of privatization. Efficiency might not always be priority number one. Almost all explanations given are that privatization is more effective than government for efficiency and cost. If this is not the case in some situations, then it is the public administrators job and for review boards to understand why. As stated above, sometimes services such as giving school children lunch or health care go above cost, and must be given.

However, more often than not, the case can be made for bad public managers either acting poorly at their job due to lack of training or know how, or acting unethically. Either case boils down to the public manager being unsuited for the position due to the ethical concerns of mismanagement and disservice to the public trust.

When the public manager is trained properly, they can make the right decisions regarding the public interest. As Cooper (2012) has stated, creating a framework helps so that when in these decisions, the ideas help flush out alternatives and solutions. One might not agree on the solutions, but the framework at least helps identify the problem and brings the attention it needs into the limelight. Creating a framework that makes the contract terms transparent to the public helps ensure fairness and equity by holding public officials accountable. 
When privatization contracts are done correctly with the public interest in mind, it can become an agreement that benefits all. Government does not choose to handle all the things it needs to accomplish by itself. Privatizing contract services out to private business is a great way to fill those needs and provide services.

In order to accomplish those goals, the public administrator must accumulate more knowledge. This includes knowledge of ethical decision making, as suggested by Cooper's framework and business knowledge. The public administrator must adapt to the changing world to keep the public interest in balance. Contract negotiations and fair dealings must be studied. Ethical training must be learned as well. Board and licensing can help ensure and review privatized contracts.

The standards of how to privatization must change. This means no more monopolies, no more closed bidding systems, no more informal handshake deals. All this can be resolved by the actions listed above. No deal will ever be perfect, and there will still be times where private business gets more than a fair deal for providing government services. However, goals are to mitigate institutionalized corruption and promote the public interest. Equity for both parties of the transaction must be met. Wasting millions of tax payer dollars on bloated contracts does not meet the public interest. As agents of the public interest, public managers must be good financial stewards. Ensuring open and ethical consideration in dealing with privatization is one way of handling this problem.

Ethical decision making includes being well trained people as well as thinking about the ethical dilemmas associated with problems. Having proper training in contract 
negotiations ensures on some part, that the public manager will not be taken advantage of in the contract situation and government can find equity in the deal.

Privatization remains an area of study and concern for the public administrator. The mix between the private and public sector has become more blurred in terms of services provided. The government cannot perform every single function it needs to perform, so it must contract out a great deal of those services. Training and review mixed with better ethical decision making will help make a more prosperous future, especially in public administration. 


\section{REFERENCES}

Baird, Alfred J., Privatization and Deregulation of Transport. London: McMillan Press, 2000

Baxandall, Phineas, Tony Dutzik and Kari Wohlschlegel. Private Roads, Public Costs: Facts about Toll Road Privatization and How to Protect the Public. US PRIG Education Fund, 2009.

Berrios, Ruben. "Government Contracts and Contractor Behavior." Journal of Business Ethics 63 (2006): 119-130.

Bowman, James. "Ethical Competency in Public Service: A Roundtable Discussion." Florida State University, 2009.

Cameron, Wayne. "Public Accountability: Effectiveness, Equity and Ethics." Australian Journal of Public Administration 63 (2004): 59-67.

Cohen, Steven. "A Strategic Framework for Devolving Responsibility and Functions from Government to the Private Sector." Public Administration Review 61 (2001): 432-440. 
"Commission on Government Forecasting and Accountability Report." State of Illinois. Accessed on August 11, 2013. http://cgfa.ilga.gov

Cooper, Terry L. The Responsible Administrator: An Approach to Ethics for the Administrative Role. New York: Wiley Co., 1998.

Ferrell, O.C. , John Fraedrich, and Linda Ferrell. Business Ethics, Ninth edition. Mason, Ohio: Cengage Learning, 2013.

United States General Accounting Office. Privatization: Lessons Learned by State and Local Governments. Report to the Chairman, House Republican Task Force on Privatization. B-271979. Washington, D.C.: U.S. United States Government Printing Office, 1997.

Ghere, Richard K. "Probing the Strategic Intricacies of Public-Private Partnership: The Patent as a Comparative Reference." Public Administration Review 661 (2001): 441-451.

Gomez-Ibanez, Jose A. and Meyer, John A. Going Private: The international Experience with Transport Privatization. Washington D.C.: Brookings Institution, 1993.

Hollingsworth, Chuck. "Reclaiming Ethics and Character for Public Service. The Public Manager 41 (2012): 60-62.

Kentucky Revised Statutes. 65, 003.

Kentucky Revised Statutes. 6, 606. 
Koven, Steven G. and Thomas S. Lyons. Economic Development: Strategies for State and Local Practice. Washington D.C.: ICMA, 2012.

Koven, Steven G. Responsible Governance: A Case Study Approach. New York: M.E. Sharpe. Inc., 2008.

Levinson, David. "Paying for the Fixed Costs of Roads." Journal of Transport Economics and Policy 39 (2005): 279-294.

Long, Norton. "Public Administration, Ethics, and Epistemology." American Review of Public Administration 18 (1988): 111-18.

Poole, Robert W. Jr. "Privatization: A New Transportation Paradigm." Annals of the American Academy of Political and Social Science 553 (1997): 94-105.

Savas, E.S. "Privatization and the New Public Management." Fordham Urban Law Journal 28 (2000): 1731.

Smith, Steven R. and Smyth, Judith. "Contracting for Services in a Decentralized System." Journal of Public Administration Research and Theory 6 (1996): 277296.

Spry, John A and Crowley, Jocelyn Elise. "Assessing the Impact of Monopoly Toll Road Service Areas." Eastern Economic Journal 30 (2004): 393-409.

Stein, Robert M. "Arranging City Services." Journal of Public Administration Research and Theory 3(1993): 66-92.

Civil Service Reform Act of 1978. 5 C.F.R. Chapter XIV, Sections 2420- 2472, Title VII. 
Van Slyke, David M. "The Mythology of Privatization in Contracting for Social Services". Public Administration Review 63 (2003): 296-315.

Waldo, Dwight. The Study of Public Administration. New York: Random House, 1955.

Wilson, Woodrow."The Study of Administration." Political Science Quarterly 2 (1887): $197-222$. 


\section{CURRICULUM VITA}

NAME:

ADDRESS:

DOB:

\section{EDUCATION}

\& TRAINING: $\quad$ B.A. Arts and Science
University of Louisville

Eric Wayne Dennison

215 Fairmeade Rd

Louisville KY, 40207

Louisville, Kentucky- March 22, 1979

2007 